\title{
Mengenali Faktor-Faktor Risiko Pasien Diabetes Melitus
}

\author{
Bagus Prakasa Sentosa \\ Program Studi Pendidikan Dokter, Fakultas Kedokteran Universitas Udayana
}

Diterima: 1 Maret 2016. Disetujui: 22 Maret 2016. Diterbitkan: Juni 2016

\section{ABSTRACT}

Background: Diabetes Mellitus (DM) remains a health problem in Indonesia as well as in many other countries. According to Medical Record of Regional Hospital of Karangasem Bali Province, the incidence of DM still high among endocrine, nutrition and metabolic diseases. About 188 cases of DM had recorded in the year 2003, 221 case in the year 2004 and 158 case in 2005. One of the strategies to decrease and manage this disease is by the screening risk factors besides an adequate therapy.

Objective: To assess the risk factors for DM such as age, family history of diabetes, dietary habits, knowledge about DM and type of personality amongst patient with DM.

Methods: A case-control study was conducted on 154 patient from Regional Hospital of Karangasem Bali Province. Cases included 79 patient identified as a DM and controls include 75 patient who did not suffer DM. Data of age, family history of diabetes, dietary habits and type of personality was taken by questionnairediabetes risk factors. Data of risk factors was obtained by a questionnaire given to 2 groups (case and control group).

Results: There was association between several risk factors and incidence of $D M$, include; age [odds ratio $(\mathrm{OR})=6,45 ; \mathrm{p}=0,000, \mathrm{PAR}=0,84]$, family history of $\mathrm{DM}(\mathrm{OR}=3,75 ; \mathrm{p}=0,001, \mathrm{PAR}=0,73)$, knowledge about $\mathrm{DM}(\mathrm{OR}=0,13 ; \mathrm{p}=0,000, \mathrm{PAR}=-6,7 /$ as a protective factor). However, there was evidence of a no association between type of personality and incidence of $D M(O R=50.4 ; p=0,479, P A R=0,98)$ and also dietary habits $(O R=1,06 ; p=0,896, P A R=006)$

Conclusion: These findings suggest a complex interaction among age factor, family history of diabetes, knowledge about DM, dietary habits and type of personality with the incidence of DM in Regional Hospital of Karangasem Bali Province.

Keywords: risk factors, diabetes mellitus, type of personality

\section{PENDAHULUAN}

Diabetes Melitus (DM) pada saat ini merupakan salah satu masalah kesehatan yang berdampak pada produktivitas dan menurunkan mutu sumber daya manusia. Penderita DM di seluruh dunia pada tahun 2025 berkisar 333 juta orang (5,4\%). Berdasarkan catatan organisasi kesehatan dunia tahun 1998, Indonesia menduduki peringkat keenam dengan jumlah penderita diabetes terbanyak setelah India, Cina, Rusia, Jepang, dan Brasil. ${ }^{1}$ Penderita DM di Indonesia semakin meningkat. Hal ini dapat diketahui bahwa pada tahun 1995 terdapat lebih kurang 5 juta penderita DM di Indonesia dengan peningkatan sekitar 230 ribu penderita setiap tahun, sehingga pada tahun 2025 penderita diabetes di Indonesia diperkirakan akan mencapai 12 juta orang. Peningkatan terjadi akibat bertambahnya populasi penduduk usia lanjut dan perubahan gaya hidup, mulai dari pola makan/jenis makanan yang dikonsumsi sampai berkurangnya kegiatan jasmani. Hal ini terjadi terutama pada kelompok usia dewasa ke atas pada seluruh status sosial-ekonomi. ${ }^{2}$ Selain itu, peningkatan jumlah kasus DM terjadi karena kurangnya tenaga kesehatan, peralatan pemantauan 
dan obat-obatan tertentu, terutama di daerah terpencil serta belum ada keseragaman dalam mengelola pasien DM oleh dokter di lini depan. ${ }^{1}$

Berdasarkan data Medical Record Rumah Sakit Umum Daerah (RSUD) Karangasem Provinsi Bali diketahui bahwa insiden DM masih merupakan penyakit yang tinggi angka kasusnya di antara penyakit endokrin, nutrisi dan metabolik. Sebanyak 188 kasus tercatat pada tahun 2003, 221 kasus di tahun 2004 dan 158 kasus pada tahun 2005. ${ }^{3}$ Berkaitan dengan permasalahan DM tersebut khususnya di RSUD Karangasem Provinsi Bali perlu dilakukan adanya skrining terhadap faktor risiko DM, sehingga penanganan dan pencegahan kasus DM dapat dilakukan lebih terarah dan disesuaikan dengan kondisi setempat serta dapat mengurangi jumlah penderita DM. Untuk itu, penelitian yang akan dilaksanakan adalah "faktor-faktor risiko apa sajakah yang menjadi determinan kasus DM di RSUD Karangasem Provinsi Bali".

\section{METODE PENELITIAN}

Jenis penelitian yang digunakan adalah penelitian analitik, dengan desain kasus-kontrol yaitu penelitian analitik observasional untuk mempelajari hubungan antara penyakit DM dengan beberapa faktor risiko. Penelitian ini dimulai dengan merekrut subjek yang berpenyakit DM dan subjek pada populasi yang sama yang tidak berpenyakit DM. Selanjutnya secara retrospektif diteliti apakah benar faktor risiko tertentu berpengaruh terhadap terjadinya penyakit. Penelitian ini dilakukan dengan membandingkan kekerapan paparan faktor risiko tersebut pada kelompok kasus dan kelompok kontrol di RSUD Karangasem Provinsi Bali. Populasi yang menjadi subjek dalam penelitian ini adalah masyarakat yang menderita DM yang dirawat di RSUD Karangasem Provinsi Bali. Selanjutnya diambil sampel penelitian yaitu penderita DM dengan kriteria diagnosis menurut American Diabetes Association. ${ }^{4}$ Selanjutnya kelompok kontrol adalah responden yang tidak menderita DM. Jumlah sampel minimal yang diperoleh berdasarkan perhitungan adalah 79 orang untuk kelompok kasus dan 75 orang kelompok kontrol.Teknik pengambilan sampel penelitian adalah purposive sampling yaitu pengambilan sampel dengan menyesuaikan kriteria tertentu (inclusion criteria) berdasarkan tujuan penelitian. ${ }^{5}$

\section{BAHAN DAN CARA PENELITIAN}

Instrumen dalam penelitian yang digunakan adalah kuesioner untuk mengukur usia, riwayat keluarga dan pola makan. Pengolahan data yang diperoleh dari hasil penelitian dikelompokkan menjadi kelompok dengan faktor risiko dan kelompok yang tidak berfaktor risiko pada kelompok kasus maupun pada kelompok kontrol. Untuk melihat hubungan antara variabel independen dan variabel independen dilakukan uji korelasi spearman rho. ${ }^{6}$ Selanjutnya untuk menetapkan pendugaan faktor risiko dengan outcome dilakukan dengan menghitung berapa seringnya terdapat paparan pada kasus dibandingkan dengan kontrol yaitu berupa odds ratio (OR). Rumus penentuan OR adalah sebagai berikut: ${ }^{7}$

$$
O R=\begin{aligned}
& A /(A+B) \\
& \{C /(C+D)
\end{aligned}: \begin{aligned}
& B /(A+B) \\
& D /(C+D)
\end{aligned}=\begin{aligned}
& A / B \\
& C / D
\end{aligned}=\begin{aligned}
& A D \\
& B C
\end{aligned}
$$

Analisis untuk menetapkan OR ini dapat dilihat pada Tabel 1.

Tabel 1. Analisis Untuk Memperoleh Nilai OR

\begin{tabular}{lcccc}
\hline & & \multicolumn{2}{c}{ Efek } & Jumlah \\
\cline { 2 - 4 } & & Kasus (+) & Kontrol (-) & \\
\hline Faktor & + & $\mathrm{A}$ & $\mathrm{B}$ & $\mathrm{A}+\mathrm{B}$ \\
Risiko & - & $\mathrm{C}$ & $\mathrm{D}$ & $\mathrm{C}+\mathrm{D}$ \\
\hline
\end{tabular}

Selanjutnya untuk lebih menjelaskan seberapa besar proporsi kasus dalam populasi penelitian akan dapat dicegah dengan menghilangkan faktor risiko maka dihitung population attributable risk (PAR), dengan rumus: $^{7}$

$$
\operatorname{PAR}=\begin{aligned}
& p(r-1) \\
& p(r-1)+1
\end{aligned}
$$

ket $: p=$ proporsi dari populasi yang terpajan

$$
r=O R
$$

Hasil penelitian akan disajikan dalam bentuk narasi dan tabel sebagai hasil akhir dari penelitian.

\section{HASIL PENELITIAN DAN PEMBAHASAN}

Berdasarkan analisis terhadap variabel usia, diperoleh gambaran bahwa kisaran usia responden pada kelompok kasus yaitu antara 21-79 tahun 
dengan rata-rata usia 54,95 tahun. Selanjutnya pada kelompok kontrol diperoleh kisaran usia antara $17-$ 69 tahun dengan rata-rata usia yaitu 45,35 tahun. Gambaran variabel pengelompokan usia responden pada subjek penelitian dapat dilihat bahwa pada kelompok kasus sebagian besar usia ${ }^{3} 45$ tahun $(88,61 \%)$, begitu juga pada kelompok kontrol (54, 67\%). Hal ini dapat dilihat pada Tabel 2.

Tabel 2. Distribusi Frekuensi Umur Responden

\begin{tabular}{crccc}
\hline \multirow{2}{*}{ Pekerjaan } & \multicolumn{4}{c}{ Kelompok } \\
\cline { 2 - 5 } & \multicolumn{2}{c}{ Kasus } & \multicolumn{2}{c}{ Kontrol } \\
\cline { 2 - 5 } & $\mathbf{f}$ & $\%$ & $\mathbf{f}$ & $\%$ \\
\hline$\geq 45$ tahun & 70 & 88,61 & 41 & 54,67 \\
$<45$ tahun & 9 & 11,39 & 34 & 45,33 \\
Total & 79 & 100 & 75 & 100 \\
\hline
\end{tabular}

Analisis data dengan menggunakan uji korelasi spearman's rho diketahui bahwa ada hubungan yang bermakna secara statistik antara umur dengan kejadian DM $(p=0,000)$. Pendugaan faktor risiko usia dengan DM didapatkan OR sebesar 6,45. (probabilitas untuk terjadinya DM pada usia <45 tahun dan 45 tahun adalah lebih kurang 1 banding 6. ${ }^{3}$ Selanjutnya Population Attributable Risk (PAR) diperoleh nilai sebesar 0,84 (sekitar $84 \%$ kasus DM dapat dicegah dengan memperhatikan faktor risiko umur). Berdasarkan analisis variabel riwayat keluarga menderita DM, diperoleh gambaran bahwa sebagian besar responden pada kelompok kasus dan kontrol tidak memiliki riwayat keluarga menderita DM yaitu $60,8 \%$ dan 85,3\%. Gambaran riwayat keluarga menderita DM responden dapat dilihat pada Tabel 3.

Tabel 3. Distribusi Frekuensi Riwayat Keluarga Menderita DM

\begin{tabular}{|c|c|c|c|c|}
\hline \multirow{3}{*}{$\begin{array}{c}\text { Riwayat Keluarga } \\
\text { Menderita DM }\end{array}$} & \multicolumn{4}{|c|}{ Kelompok } \\
\hline & \multicolumn{2}{|c|}{ Kasus } & \multicolumn{2}{|c|}{ Kontrol } \\
\hline & $f$ & $\%$ & $f$ & $\%$ \\
\hline $\mathrm{Ya}$ & 31 & 39,2 & 11 & 14,7 \\
\hline Tidak & 48 & 60,8 & 64 & 85,3 \\
\hline Total & 79 & 100 & 75 & 100 \\
\hline
\end{tabular}

Analisis data dengan menggunakan uji korelasi spearman's rho diketahui bahwa ada hubungan yang bermakna secara statistik antara riwayat keluarga menderita DM dengan kejadian DM ( $p=0,001)$. Pendugaan faktor risiko riwayat keluarga dengan DM didapatkan OR sebesar 3,75 (probabilitas untuk terjadinya DM pada orang dengan tidak ada riwayat keluarga menderita DM dan ada riwayat keluarga adalah lebih kurang 1 banding 4. Selanjutnya PAR iperoleh nilai sebesar 0,73 (sekitar 73\% kasus DM dapat dicegah dengan memperhatikan faktor risiko adanya riwayat keluarga menderita DM) Berdasarkan analisis variabel pengetahuan responden, diperoleh gambaran bahwa sebagian besar responden pada kelompok kasus dan kontrol kriteria pengetahuannya adalah baik yaitu $94,9 \%$ dan $68,0 \%$.Gambaran pengetahuan responden tentang DM dapat dilihat pada Tabel 4.

Tabel 4. Distribusi Frekuensi Pengelompokan Pengetahuan Responden tentang DM

\begin{tabular}{ccccr}
\hline $\begin{array}{c}\text { Kategori } \\
\text { Pengetahuan }\end{array}$ & \multicolumn{2}{c}{$\begin{array}{c}\text { Kelompok } \\
\text { Kasus }\end{array}$} & \multicolumn{2}{c}{$\begin{array}{c}\text { Kelompok } \\
\text { Kontrol }\end{array}$} \\
\cline { 2 - 5 } & $\mathbf{f}$ & $\%$ & f & $\%$ \\
\hline Kurang (skor 0-49) & 4 & 5,1 & 24 & 32 \\
Baik (skor 50-100) & 75 & 94,9 & 51 & 68 \\
Total & 79 & 100 & 75 & 100 \\
\hline
\end{tabular}

Analisis data dengan menggunakan uji korelasi spearman's rho diketahui bahwa ada hubungan yang bermakna secara statistik antara pengetahuan dengan kejadian DM $(p=0,000)$. Pendugaan faktor risiko pengetahuan responden tentang DM didapatkan OR sebesar 0,13 (probabilitas untuk terjadinya DM pada orang dengan pengetahuan baik tentang DM dan pengetahuan yang kurang baik tentang DM adalah 0 banding 1 . Selanjutnya PAR diperoleh nilai sebesar $-6,7$ (pengetahuan sebagai faktor protektif). Berdasarkan analisis variabel pola makan responden, diperoleh gambaran bahwa sebagian besar responden pada kelompok kasus dan kontrol berpola makan tidak sehat yaitu $86,1 \%$ dan $85,3 \%$. Gambaran variabel pola makan responden pada subjek penelitian dapat dilihat pada Tabel 5.

Tabel 5. Distribusi Frekuensi Pola Makan Responden

\begin{tabular}{lcccc}
\hline \multirow{2}{*}{ Pola makan } & \multicolumn{4}{c}{ Kelompok } \\
\cline { 2 - 5 } & \multicolumn{2}{c}{ Kasus } & \multicolumn{2}{c}{ Kontrol } \\
\cline { 2 - 5 } & $\mathbf{f}$ & $\%$ & $\mathbf{f}$ & $\%$ \\
\hline Tidak sehat & 68 & 86,1 & 64 & 85,3 \\
Sehat & 11 & 13,9 & 11 & 14,7 \\
\multicolumn{1}{c}{ Total } & 79 & 100 & 75 & 100 \\
\hline
\end{tabular}

Analisis data dengan menggunakan uji korelasi spearman's rho diketahui bahwa tidak terdapat hubungan yang bermakna secara statistik antara pola makan dengan kejadian DM $(p=0,896)$. Pendugaan 
faktor risiko pola makan didapatkan OR sebesar 1,06 (probabilitas untuk terjadinya DM pada orang dengan pola makan tidak sehat dan pola makan sehat adalah lebih kurang sama atau 1 banding 1 . Selanjutnya PAR diperoleh nilai sebesar 0,06 (sekitar $6 \%$ kasus DM dapat dicegah dengan menghilangkan faktor risiko adanya pola makan yang tidak sehat). Berdasarkan analisis variabel pola kepribadian menderita DM diperoleh gambaran bahwa sebagian besar responden pada kelompok kasus dan kontrol berpola kepribadian typeA/B dan B personality yaitu $59,5 \%$ dan $98,7 \%$. Gambaran pola kepribadian responden dapat dilihat pada Tabel 6 .

Tabel 6. Distribusi Frekuensi Pengelompokan Pola Kepribadian Responden

\begin{tabular}{ccccc}
\hline \multirow{2}{*}{ Pola Kepribadian } & \multicolumn{2}{c}{$\begin{array}{c}\text { Kelompok } \\
\text { Kasus }\end{array}$} & \multicolumn{2}{c}{$\begin{array}{c}\text { Kelompok } \\
\text { Kontrol }\end{array}$} \\
\cline { 2 - 5 } & $\mathbf{f}$ & $\%$ & f & $\%$ \\
\hline Type A personality & 32 & 40,5 & 1 & 1,3 \\
Type A/B dan B personality & 47 & 59,5 & 74 & 98,7 \\
Total & 79 & 100 & 75 & 100 \\
\hline
\end{tabular}

Analisis data dengan menggunakan uji korelasi spearman's rho diketahui bahwa tidak terdapat hubungan yang bermakna secara statistik antara pola kepribadian dengan kejadian DM ( $p=0,479)$. Pendugaan faktor risiko pola kepribadian responden didapatkan OR sebesar 50,4 (probabilitas untuk terjadinya DM pada orang dengan type kepribadian A/B dan B dan type kepribadian A adalah lebih kurang 1 banding 50. Selanjutnya PAR diperoleh nilai sebesar 0,98 (sekitar 98\% kasus DM dapat dicegah dengan menghilangkan faktor risiko adanya pola kepribadian type A). Berdasarkan pengolahan dan analisis data diketahui terdapat hubungan yang bermakna antara umur dengan kejadian DM. Pendugaan faktor risiko usia dengan DM didapatkan bahwa probabilitas untuk terjadinya DM pada usia <45 tahun dan 45 tahun adalah lebih kurang 1 banding 6 dengan asumsi sekitar 84\% kasus DM dapat dicegah dengan memperhatikan faktor risiko umur. Hal ini sesuai dengan teori yang mengatakan bahwa mereka dengan usia lebih dari 45 tahun adalah kelompok usia yang berisiko menderita DM.8 Lebih lanjut dikatakan bahwa DM merupakan penyakit yang terjadi akibat penurunan fungsi organ tubuh (degeneratif) terutama gangguan organ pangkreas dalam menghasilkan hormon insulin, sehingga DM akan meningkat kasusnya sejalan dengan pertambahan usia. ${ }^{9}$

Hasil penelitian ini sejalan dengan penelitian sebelumnya di Jakarta ${ }^{10}$ dan di Padang ${ }^{11}$, menunjukkan bahwa kelompok umur 50-60 tahun (di atas 45 tahun) adalah kelompok yang terbanyak menderita DM dibanding kelompok umur di bawahnya. Angka kasus DM akan meningkat sesuai dengan pertambahan usia. Selain itu, DM disebut juga sebagai salah satu penyakit degeratif karena adanya gangguan metabolisme karbohidrat, lemak dan protein serta ditandai dengan tingginya kadar gula dalam darah (hiperglikemia) dan dalam urin (glukosuria). Berdasarkan pengolahan dan analisis data diketahui terdapat hubungan yang bermakna antara riwayat keluarga menderita DM dengan kejadian DM. Dapat diketahui pula bahwa jumlah yang memiliki riwayat keluarga menderita DM lebih banyak pada kelompok kasus. Pendugaan faktor risiko riwayat keluarga dengan DM diperoleh probabilitas untuk terjadinya DM pada orang dengan tidak ada riwayat keluarga menderita DM dan ada riwayat keluarga adalah lebih kurang 1 banding 4 dengan asumsi sekitar 73\% kasus DM dapat dicegah dengan memperhatikan faktor risiko adanya riwayat keluarga menderita DM. Salah satu kelompok yang berisiko tinggi menderita DM jika ada salah satu yang mempunyai keturunan baik pada orang tuanya atau kakeknya, saudaranya dan lain-lain yang menderita DM. Faktor risiko keluarga lain adalah mereka yang melahirkan anak di atas $4 \mathrm{~kg}$ (gestasional DM).12 Berdasarkan pengolahan dan analisis data diketahui terdapat hubungan yang bermakna antara pengetahuan tentang DM dengan kejadian DM. Dapat diketahui bahwa jumlah yang memiliki pengetahuan tidak baik lebih banyak pada kelompok kontrol. Pendugaan faktor risiko pengetahuan responden tentang DM diperoleh bahwa OR sebesar 0,13 dengan asumsi probabilitas untuk terjadinya DM pada orang dengan pengetahuan baik tentang DM lebih tinggi daripada pengetahuan yang kurang baik tentang DM yaitu PAR diperoleh nilai sebesar 6,7 (pengetahuan sebagai faktor protektif). Rendahnya tingkat pendidikan dan pengetahuan merupakan salah satu penyebab tingginya angka kasus suatu penyakit. Pengetahuan bisa diperoleh 
melalui upaya promosi kesehatan. $^{13}$ Promosi kesehatan yang meliputi pendidikan kesehatan, faktor ekonomi dan lingkungan mendukung terbentuknya perilaku sehat dan dapat menurunkan faktor risiko DM. ${ }^{14,15}$ Ketidaktahuan seseorang tentang sesuatu dalam hal ini tentang DM tentunya akan meningkatkan risiko orang tersebut untuk menderita DM. Pada kenyataannya hasil temuan menemukan bahwa pada kelompok kasus lebih banyak yang berpengetahuan baik dari pada kelompok kontrol. Hal ini disebabkan karena sebagian besar penderita DM (kelompok kasus) sudah menderita DM selama bertahun-tahun, sehingga mereka mencari sumbersumber informasi tentang DM. Seseorang cenderung berusaha mencari tahu atau mencari informasi setelah ia mengalami gangguan/masalah atau berusaha mencari tahu apa permasalahan yang sedang dihadapi dan bagaimana pemecahannya. Selain itu, hal ini terjadi karena pengukuran pengetahuan dilakukan bersamaan waktunya dengan penelitian. Dengan kata lain bukan pengetahuan yang dimiliki sebelum responden menderita DM, sehingga hasil temuan sedikit bias dari teori karena diperoleh pengetahuan yang lebih baik ternyata dimiliki lebih banyak oleh kelompok kasus. Berdasarkan pengolahan dan analisis data diketahui tidak terdapat hubungan yang bermakna antara pola makan dengan kejadian DM. Dapat diketahui bahwa jumlah yang memiliki pola makan tidak sehat sedikit lebih banyak pada kelompok kasus. Pendugaan faktor risiko pola makan diketahui bahwa OR sebesar 1,06 yang artinya probabilitas untuk terjadinya DM pada orang dengan pola makan tidak sehat dan pola makan sehat adalah lebih kurang sama atau 1 banding 1 . Selanjutnya dari nilai PAR diketahui sekitar 6\% kasus DM dapat dicegah dengan menghilangkan faktor risiko adanya pola makan yang tidak sehat. Pola makan (dietary habits) yang tidak sehat, seperti makan-makanan yang berlebihan atau kelebihan zat-zat nutrisi seperti karbohidrat merupakan faktor risiko untuk terjadi DM. Berdasarkan pengolahan dan analisis data diketahui tidak terdapat hubungan yang bermakna antara pola kepribadian dengan kejadian DM. Dapat diketahui pula bahwa jumlah yang memiliki kepribadian tipe A lebih banyak pada kelompok kasus. Pendugaan faktor risiko pola kepribadian responden diperoleh bahwa OR sebesar 50,4 yang artinya probabilitas untuk terjadinya DM pada orang dengan tipe kepribadian $A / B$ dan $B$ dan tipe kepribadian $A$ adalah lebih kurang 1 banding 50 dimana dari nilai PAR diperoleh sekitar 98\% (kasus DM dapat dicegah dengan menghilangkan faktor risiko adanya pola kepribadian tipe $\mathrm{A})$. Hal ini sesuai dengan teori yang mengatakan bahwa orang dengan aktivitas fisik yang kurang dan mengalami stres psikososial serta individu dengan gaya hidup yang agresif, selalu berkompetisi (type A personality) atau biasa juga disebut dengan sedentary person merupakan faktor risiko menderita DM (pre-diabetic risk factor). ${ }^{8}$

\section{SIMPULAN DAN SARAN}

Probabilitas untuk terjadinya DM pada usia $<45$ tahun dan 45 tahun adalah lebih kurang 1 banding 6 dengan pendugaan/asumsi sekitar $84 \%$ kasus DM dapat dicegah dengan memperhatikan faktor risiko umur. Probabilitas untuk terjadinya DM pada orang dengan tidak ada riwayat keluarga dan ada riwayat keluarga menderita DM adalah lebih kurang 1 banding 4, dengan asumsi sekitar 73\% kasus DM dapat dicegah dengan memperhatikan faktor risiko ini. Probabilitas untuk terjadinya DM pada orang dengan pola makan tidak sehat dan pola makan sehat adalah lebih kurang sama yaitu 1 banding 1 . Namun diasumsikan sekitar 6\% kasus DM dapat dicegah dengan menghilangkan faktor risiko adanya pola makan yang tidak sehat. Pendugaan probabilitas untuk terjadinya DM pada orang dengan pengetahuan baik tentang DM lebih tinggi daripada pengetahuan yang kurang baik tentang DM yaitu PAR diperoleh nilai sebesar -6,7 (pengetahuan sebagai faktor protektif). Pendugaan faktor risiko pola kepribadian responden diperoleh bahwa probabilitas untuk terjadinya DM pada orang dengan type kepribadian $A / b$ dan $B$ dan tipe kepribadian $A$ adalah lebih kurang 1 banding 50 yaitu dari nilai PAR diperoleh sekitar 98\% kasus DM dapat dicegah dengan menghilangkan faktor risiko adanya pola kepribadian tipe A. Berdasarkan hasil penelitian diperoleh bahwa kelompok usia 45 tahun atau lebih, memiliki riwayat keluarga dengan DM merupakan 


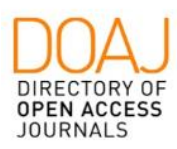

kelompok usia yang berisiko menderita DM, begitu juga kelompok dengan pola makan yang tidak sehat dan pola kepribadian type A merupakan kelompok yang berisiko menderita DM, sehingga pada kelompok masyarakat ini dianjurkan untuk melakukan pemeriksaan/ screening test terutama untuk deteksi dini adanya gejala-gejala prediabetes dan diabetes.

\section{DAFTAR PUSTAKA}

1. Soegondo. Penderita Diabetes di Indonesia Capai 12 Juta Orang. Copyright (c) 2003 Banjarmasin Post. Kamis, 13 Januari 2005 15:56:22 WIB. Available:

http://pdpersi.pdpersi.co.id/pdpersi/news/

Cakrawala .php3? id=2994. Diakses tanggal 2 Agustus 2005

2. Direktur Gizi Masyarakat Dirjen BinKesMasy DepKes RI. Diabetes dan Pencegahannya. Jakarta. 2003.

3. Glanz, K., F.M. Lewis and B.K. Rimer. Health Behavior and Health Education. San Francisco, CA, Jossey-Bass Publishers. 1997.

4. American Diabetes Association. Standards of Medical Care in Diabetes. Clinical Practice Recommendations 2005. Diabetes Care, 28(Suppl): S4-S36. 2005. Available at: http:// health. yahoo.com/ency/ healthwise/tj4293. Diakses 11 Agustus 2005.

5. Singarimbun, M., Effendi, S. Metode Penelitian Survey. Edisi ke empat, LP3ES. Jakarta. 1984. 6. Sugiyono. Stastitika untuk Penelitian, CV Alfabeta, Bandung. 2000.

7. Sastroasmoro, S. Ismael, S. Dasar-dasar Metode Penelitian Klinis. Bagian IImu Kesehatan Anak Fakultas Kedokteran Universitas Indonesia. Jakarta. 1995.

8. www.dlife.com, Prediabetes Risk Factor. 2005. Available: http//www.dlife.com. Diakses tanggal 8 Agustus 2005

9. Park, P.J., Griffin, S.J., Sargeant, L., Wareham, N.J. The performance of a risk score in Predicting Undiagnosed Hyperglycemia. Diabetes Care. 2002; 25:984-8.

10. Heridarwanto et al. Pola Penderita Diabetes Melitus yang Dirawat di Bagian Penyakit Dalam
RS Persahabatan. Naskah Lengkap. Kongres Nasional I PERKENI. Jakarta. 1996.

11. Hendrizal, I. Karakteristik Penderita Diabetes Mellitus di RSUP Dr. M. Djamil Padang. Skripsi. Fakultas Kedokteran Universitas Andalas Padang. 1996.

12. Loetan, F. Diabetes Mellitus. 1997. Available at: http:// www.pacific.net.id/doctor/sexp/artikel/ as971225. html. Diakses 11 Agustus 2005.

13. Notoatmodjo, S. IImu Kesehatan Masyarakat (edisi pertama). Rineka Cipta. Jakarta. 1997.

14. Green, L.W. and M.W. Kreuter. Health Promotion Planning: An Educational and Environmental Approach. Mountain Vi e w, CA, Mayfield. 1991.

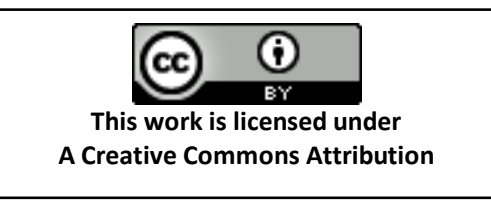

